\title{
Digital art application development: A project to increase motivation in systems development courses for bachelor students in computer engineering
}

\author{
Anniken Karlsen and Robin T. Bye \\ Aalesund University College, Aalesund, Norway \\ $\{a k$, roby $\} @$ hials.no
}

\begin{abstract}
In this demonstration, we present some in-progress results of using digital art application development as an example of entertainment computing for increasing motivation and participation in a computer engineering undergraduate systems development course, with the purpose of improving the chances of reaching the intended learning outcomes. By stimulating motivation and participation via an openly defined project description of making an interactive art application in a competitive context, a variety of interesting project outcomes were produced, despite the fact that the project did not count towards the final grading of the course. The students made their applications by combining existing programming skills with the programming language Processing, lessons in Human-Computer-Interaction and software development methodologies.

Keywords: Art and motivation; Creative activities; Digital creativity; Teaching; Software engineering
\end{abstract}

\section{Introduction}

Aalesund University College (AAUC) offers a variety of bachelor education programs. As part of becoming a computer engineer, software development is vital. Programming is introduced in the first study year. In the second year, this competence is further developed. Specifically, in the fourth semester course Systems Development and Modeling, the teachers have been trying for years to increase the motivation for projects where the outcome does not directly count as a grading criterion, only the final exam does. Last year a competition project was initiated based on requirements and specifications from a private company [1]. This year another competition was initiated. This time the project mission was provided by the teachers and deliberately made more open, with the goal of developing a digital art application as an example of entertainment computing to stimulate creativity and fun as part of the development process.

The use of digital technology in contemporary art is often referred to as new media 
art [2]. Software engineering, including systems development and modelling, are key elements in succeeding bridging the gap between the worlds of the computer programmer and the artist. In higher education, the combination of art and computing can be used for the benefit of attracting students to computer science and providing a stimulating framework for studying software engineering issues (e.g., see [3]).

The idea of using entertainment computing such as new media technology for teaching computer engineering courses is not new. Whilst the domain of entertainment technology can be divided into the four fields of games; sports; novels and movies; and art [4], there seems to be a focus in computing education on programming computer games (e.g., simple versions of classic games like Pac-Man or Space Invaders) or toy robots such as Lego Mindstorms (mindstorms.lego.com) [5]. Indeed, at AAUC, we are using the highly advanced, yet easy to use 3D game engine Unity (www.unity3d.com) for a variety of courses as well as for research. In this paper, on the other hand, our approach of using digital art as the vehicle for teaching a computer engineering course appears to be a less trodden path.

Central to the course and its use of the above mentioned student project is the adoption of an active learning paradigm, which is dominant in many of the engineering courses taught at AAUC and have recently also been the focus of education research in a joint computer and automation engineering course on microcontrollers offered at AAUC [6]. A key factor for achieving intended learning outcomes is the students' approach to learning [7, 8]. Many studies have tried to identify factors that promote deeper learning [e.g., 9,10], that is, learning associated with understanding in contrast with surface learning, where focus is on memorizing facts and procedures, and with little or no understanding as a result [8]. According to one definition by Prince [11], active learning is any learning activity or teaching method that actively involves the students in the learning process, usually associated with cooperative learning, problem-based learning, and practical exercises. Of these learning activities, particularly cooperative learning strategies have shown the best learning effects [e.g. $12,13,14$, and 15].

Common characteristics of new media include new types of entertainment experiences; interactive as opposed to passive experiences; and integration of spatial, social, mental, and physical presence [16]. The creation of a digital art application as presented here encompasses much of these in an "integrated presence" [16], combining physical presence (team work, programming, discussions, etc.) with mental presence (study literature, watch and judge the art created by the application, etc.). Indeed, computer programming is a creative form of art itself, which combined with the excitement of creating an interactive art application triggers a number of enjoyable entertainment experiences such as curiosity, pleasingness, pride, perception of being in control, etc. [17].

\section{About the project}

The class of 24 students was divided into 6 groups, each with 4 students. All groups were given the same task of designing an interactive application for generating digital 
art but were free to approach the problem as they desired. When first introducing the project to the students, they seemed surprised. One student stated that he was not into art and did not feel particularly creative. Another stated that he had no insight into visualization and animation. A third stated that programming was not among his favorites. He therefore worried that the project would be too demanding. As a response to these worries, the students were shown a variety of visual art applications found on the Internet. They were also introduced to Processing, a programming language created to make programming interactive graphics easier [18]. The language was made by Reas and Fry who were frustrated with how difficult it was to write this type of software with the programming languages they usually used [19]. By combining Processing with previous insights into the Java programming language, soon after the students made colorful lines and figures on the screen. Many of these became blueprints and ideas for brushes, a basic painting tool, to be found in the future art applications. Some of the students seemed amazed of what they were able to make and words like fun and interesting started to fill the room.

Stimulating creativity is one of the aspects highlighted by the Norwegian Ministry of Knowledge in the national curriculum for 3-year bachelor degrees in engineering (Universities and Colleges Act, 2005) [20], based on the vision of an engineer as socially committed, creative and dynamic, with the ability to actively contribute to future challenges. Adding to this, The National Council for Technological Education [21] in their guidelines for engineering education also emphasizes the ability to be skilled at working independently as well as in engineering teams. Obviously, letting the students collaborate in groups with much freedom in choosing their own design decisions stimulated both creativity and dynamic teamwork. The students eagerly investigated how they could use their previous programming knowledge together with the capabilities of Processing to make an application for generating artistic pictures. They got new ideas, and some of them seemed to burst into excitement.

\section{Competition and creativity as a driving force for learning}

To develop the art applications the students started by investigating the capabilities of Processing [19] as a programming tool. By challenging them to first make some simple forms and figures and then systematically making the tasks more complicated they all showed great progress in making visualizations and animations on the screen. Between lectures the students continued the work at school or at home. They all used an agile development method with several meetings and incremental deliveries.

The teachers' main experience was that the climate of positive competition mixed with creative thinking and doings improved motivation and thereby increased student participation even though the project did not per se count on the grading. One of the students stated that he now saw programming as fun and engaging. Another highlighted that he had never experienced such a progression in obtaining knowledge in other courses he had attended. 


\section{$4 \quad$ Awards ceremony for worthy winners}

On the final day of the course, each student group demonstrated their application to the other student groups and a jury panel of externals (see Fig. 1 for a screenshot).

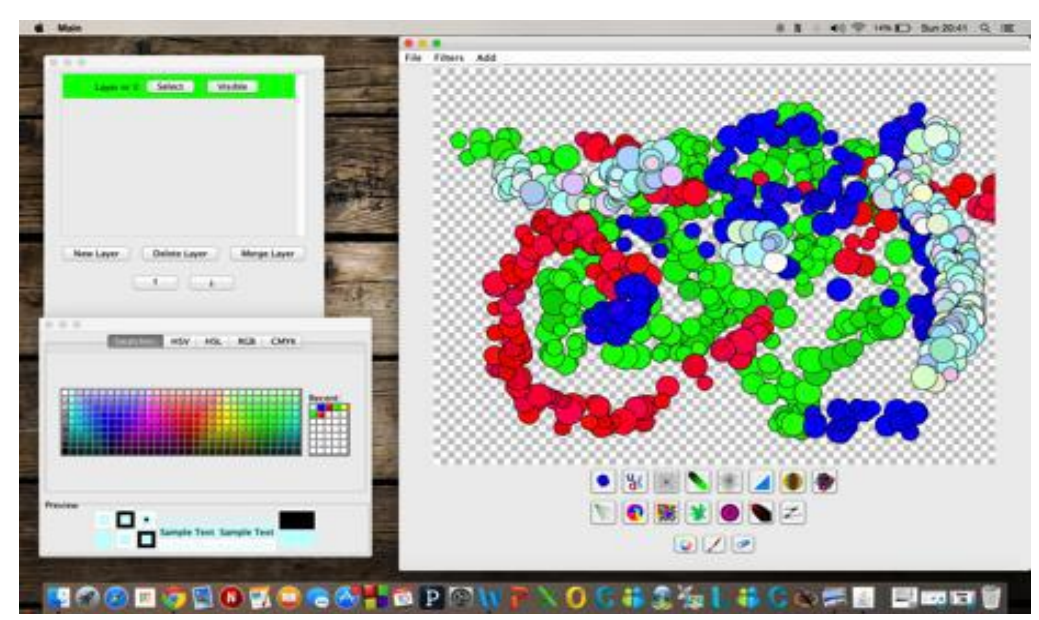

Fig. 1. Screenshot from one of the applications

The panel was invited to choose the winner app and constituted one academic, one architect, one professional artist and one person from a private computer company. The teachers themselves did not take part in the formal evaluation to pick a winner. The jury did an overall evaluation based on the technical quality and complexity of the app, its usability, the artistic quality of the generated art, and the presentation skills of the group. An artistic lithograph was given to each member of the winning group and the second best group.

\section{$5 \quad$ Results and conclusions}

The main project outcomes reported by the students were joy, engagement and increased capability and trust in their personal software development skills by having developed creative applications. The need to make decisions on their own mixed with an informal creative competition made this a continuous learning process motivating further engagement in programming and graphics.

As teachers, we observed that the students were able to write large and complex software, integrating and synthesizing computer code and libraries readily available with their own code tailored for their own art application. Thus, the student project served as a suitable practical test-bed for the various theoretical aspects of the course. It is also worth mentioning that the class results from the final examination were overall very good although we have no rigorous evidence linking the project to these results at this time. Finally, a number of in-depth tape-recorded interviews with students in focus groups will be analyzed with the prospect of further improving the 
course design and informing future research. We will report on the findings from the interviews in a subsequent paper.

According to [6], there are at least three important factors for succeeding with an active learning paradigm as presented in this paper. The first factor is the effect of instant feedback, which is well known as a basis in behavioral learning. Programming graphical art applications gave the students immediate feedback about their code and if something was working or not, thus the positive effect of instant feedback was achieved. The second factor is the bi-directional interaction between lectures and practical work, where both affect each other positively. The project served as a suitable domain for applying theory, thus making lectures more worthwhile and easy to absorb. The third factor is related to critique against problem-based learning in the literature. According to a survey of 800 meta-studies, Hattie [22] found that problembased learning has no effect on achieving intended learning outcomes. Instead, there is a positive effect from problem-solving learning [6]. The reason for this is likely provided by Sotto [23], who claims that students spend too much time searching and sorting information in problem-based learning compared to problem-solving learning. Presumably, it appears that the readiness of available tools, an easy-to-use programming language like Processing, and the immediate visual feedback turned our project into a problem-solving one, where students quickly were able to focus on solving the actual problem.

In this demonstration, we illustrate tangible results from the art application competition, remembering that these are applications made by teams of students that in advance did not feel particularly creative and/or capable of making art on the computer screen. The end-results obviously proved them wrong.

\section{Acknowledgements}

The authors wish to thank our enthusiastic students and in particular the winning group consisting of Stein Sæter, Terje Eik, Erik Espenakk, and Tony André Haugen. In addition, we are grateful for the valuable insight provided by Professor Letizia Jaccheri during the preparation of this paper.

\section{References}

1. Karlsen, A., Kristiansen, H.: Undervisningsrefleksjoner fra et konkurranseprosjekt i samarbeid med næringslivsaktør. Norsk konferanse for organisasjoners bruk av informasjonsteknologi (NOKOBIT 2014). Open Access at http://obj.bibsys.no/index.php/NOKOBIT/ index

2. Trifonova, A., Jaccheri, L. and Bergaust, K.: Software engineering issues in interactive installation art, Int. J. Arts and Technology, Vol. 1, No. 1, pp.43-65 (2008)

3. Giannakos, M. N. and Jaccheri, L.: Designing creative activities for children: the importance of collaboration and the threat of losing control. Proceedings of the 12th International Conference on Interaction Design and Children. ACM (2013)

4. Altman, E. \& Nakatsu, R. Interactive Movies: Techniques, Technology and Content. Course Notes, No. 16, ACM SIGGRAPH'97 (1997) 
5. Overmars, M. Teaching computer science through game design. Computer, 37(4), 81-83 (2004)

6. Schaathun, W., Schaathun, H.G., and Bye, R.T.: Aktiv læring i mikrokontrollarar. Artikkel presentert på MNT- konferansen 2015 og under vurdering for publisering i Uniped (2015)

7. Gynnild, V.: Læringsorientert eller eksamensfokusert? Nærstudier av pedagogisk utviklingsarbeid i sivilingeniørstudiet. PhD, NTNU, Trondheim (2001)

8. Marton, F.: Phenomenography - describing conceptions of the world around us. Instructional Science, 10, 177-200 (1981)

9. Marton, F., \& Booth, S.: Learning and awareness. Mahwaw, NJ: Lawrence Erlbaum (1997)

10. Prosser, M., \& Trigwell, K.: Understanding learning and teaching: The experience on higher education. Buckingham: Society for Research in Higher Education / Open Univeristy Press (1999)

11. Prince, M. J.: Does active learning work? A review of the research. Journal of Engineering Education, 93(3), 223-231 (2004)

12. Bowen, C. W.: A Quantitative Literature Review of Cooperative Learning Effects on High School and College Chemistry Achievement. Journal of Chemical Education, 77(1), 116 (2000)

13. Foldnes, N.: Cooperative Learning in the Flipped Classroom: A Randomized Experiment. Unpublished manuscript (2014)

14. Johnson, D., Johnson, R., \& Smith, K.: Active Learning: Cooperation in the College Classroom (2 utg.). Edina: Interaction Book Co. (1998)

15. Springer, L., Stanne, M., Donovan, S.: Effects of small-group learning on undergraduates in science, mathematics, engineering and technology: A meta-analysis. Review of Educational Research, 69(1), 21-52 (1999)

16. Nakatsu, R., Rauterberg, M., \& Vorderer, P. A new framework for entertainment computing: from passive to active experience. In Entertainment Computing-ICEC 2005 (pp. 112). Springer Berlin Heidelberg (2005)

17. Vorderer, P., Klimmt, C., \& Ritterfeld, U. Enjoyment: At the heart of media entertainment. Communication theory, 14(4), 388-408 (2004)

18. Greenberg, I., Xu, D., Kumar, D.: Processing - Creative coding and Generative Art in Processing 2. Friendsof - an Apress company (2013)

19. Reas, C., Fry, B.: Getting Started with Processing. O’Reilly (2010)

20. Kunnskapsdepartementet. Ny forskrift om rammeplan for ingeniørutdanning, Kunnskapsdepartementets internettside med lenke til lovdata: http://lovdata.no/dokument/ SF/forskrift/2011-02-03-107 (2011)

21. Nasjonalt råd for teknologisk utdanning. Nasjonale retningslinjer for ingeniørutdanning: På vei mot fremtiden! (2011). Downloaded 11.05.2015 at: http://www.uhr.no/documents/ Nasjonale_retningslinjer_for_ingeni_rutdanning_ENGELSK.pdf

22. Hattie, J.: Visible learning: A synthesis of over 800 meta-analyses relating to achievement. Routledge (2013)

23. Sotto, E.: When teaching becomes learning: A theory and practice of teaching (2nd ed.). London: Continuum (2007) 